\title{
EDITORIAL
}

\section{The bacteriological examination of drinking water}

It is difficult to over-emphasize the importance of an adequate supply of wholesome drinking water to any community. Twenty years ago Campbell (1959) estimated that each year some 500 million people worldwide were affected by incapacitating waterborne or water-associated disease and that 10 million of these died. It is unlikely that today, as we enter the third year of the International Drinking Water Supply and Sanitation Decade, the position is greatly different. Indeed, a more recent estimate (Witt, 1982), based on WHO reports suggests that $80 \%$ of all human illness in the developing world is associated with polluted water, and that most of those illnesses are caused by biological contamination.

In more fortunate areas, such as the United Kingdom, the provision of safe, wholesome drinking water often seems to be taken for granted, and it is easy to forget the sheer scale of organization and expertise necessary to ensure the integrity of our water supplies. Failures are rare, but an incident which affected Bramham, in Yorkshire, in June 1980, in which sewage from a blocked sewer reached a borehole, and co-incident failure of chlorination allowed contamination of the public water supply, underlines the need for constant vigilance. In this incident more than a thousand people suffered a sharp attack of gastro-enteritis, and it was fortunate that there were no more serious illnesses.

In the United Kingdom there are obligations under Water and Public Health Legislation for water undertakings to supply wholesome water, and for local authorities to monitor the wholesomeness and sufficiency of supplies in their areas. Prior to 1974 there existed separate authorities concerned with water supply, sewerage and sewage disposal, and rivers and water resource management. In 1973 the Department of the Environment became responsible for all aspects of the water cycle, and on 1 April 1974, the water supply, sewerage and water resource services were amalgamated. Nine regional water authorities were created in England and Wales, together with the Welsh National Water Development Authority and later the National Water Council. By the time this paper is in print current legislation may well have changed the picture again. In particular, the National Water Council itself may have ceased to exist.

The various water undertakings have a duty to supply wholesome and therefore safe and aesthetically acceptable water for drinking, but until recently there have been no legally enforceable standards for the chemical or microbial quality of drinking water in the United Kingdom. Standards have been applied, and in general have conformed to those of the World Health Organisation (WHO 1970, 1971, 1976). More particularly they have conformed to the standards advocated in the Department of Health and Social Security Reports on Public Health and Medical Subjects, No. 71, on the Bacteriological Examination of Water Supplies, affectionately known as 'Report 71', the fifth edition of which (DHSS 1982) has just been published. 
The first edition of Report 71 was prepared in 1934 by a small committee under the chairmanship of the late Dr Thomas Carnworth, with the following objectives:

(1) To provide a description of technique, the adoption of which will ensure sufficient uniformity in the practice of bacteriological examination of water to permit of comparison of the results obtained in different laboratories.

(2) To explain to sanitary inspectors and others the precautions necessary in obtaining and transmitting samples to the laboratory.

(3) To assist in assessing the results of bacteriological examination in terms of hygienic quality.

With relatively minor changes in emphasis, these objectives have formed part of the aims of all later editions. The first document still makes fascinating reading, and lays down many principles which have since become standard practice in this field. In particular it sets out the first tentative justification for the use of tests for indicator organisms as indices of faecal pollution and therefore as indicators of the possibility that pathogenic organisms might also be present, rather than tests for pathogenic organisms themselves, in the routine assessment of the bacteriological safety of drinking water. This has now become established as one of the fundamental principles of the bacteriological examination of water supplies, in which the concern of the bacteriologist is not so much whether the water does contain pathogenic organisms as whether it could do so. If there are no faecal commensal organisms present, there are not likely to be any faecal pathogens either.

The Public Health Laboratory Service (PHLS), which was formed initially as an emergency laboratory service just before the outbreak of World War II in order to control outbreaks of infectious disease which were expected to arise following either the disruption of water supplies and sewerage by enemy action or in the event of germ warfare, has, since its inception, been closely concerned with the bacteriological safety of water supplies. The PHLS assumed responsibility for Report 71 in 1956, and, through its water committee and with help from colleagues in the water industry, undertook the task of updating and revising the third and fourth editions.

When the Department of the Environment became responsible in 1973, for all aspects of the water cycle, the Department established a Standing Committee of Analysts (SCA) to review and keep up to date the methods, both chemical and microbiological, recommended for water examination in the United Kingdom. The SCA convened a joint panel, under the chairmanship of Dr. G. I. Barrow, consisting of the Water Committee of the PHLS and microbiologists from water authorities, with the task of completely revising Report 71. The present, fifth, edition is the result. It is a comprehensive review of the principles and detailed techniques appropriate to the bacterial examination of drinking water at all stages from source to consumer. As in previous editions, changes proposed in the technical section have been based on experimental work carried out by members of the panel, and published in this Journal (PHLS/SCA 1980a-c, 1981). This has mainly concerned detailed comparisons of different media used to detect and confirm the identity of Escherichia coli present in small numbers in different water samples. The main changes in the Report, apart from format and revision of the technical methods, include the introduction of a classification for potable supplies according 
to the coliform results, to highlight those particularly in need of attention, and recommendations for minimum surveillance programmes based on the size of population served. The value of independent random consumer samples taken on behalf of local authorities is reaffirmed.

During the preparation of the Report, the Council of the European Communities issued a directive relating to the quality of water intended for human consumption, the E.C. Directive (European Community, 1980). This directive lists sixty-four chemical and microbiological parameters for water quality standards and steps must be taken to ensure full compliance with the standards specified by $18 \mathrm{July}$, 1985. It can be said at once that the provisions of the directive ask for no more than has been regarded as good practice in the United Kingdom for many years. The directive will therefore underline and reinforce, rather than alter, existing policy and procedures (DOE/WO,1982). In particular, if the monitoring programme for the bacteriological examination of water recommended in Report 71 is followed by water undertakings and local authorities, the bacteriological requirements of the directive will be more than satisfied.

The directive has, however, other far reaching implications. It applies to all water intended for human consumption, and it applies at the consumer's tap. It is manifestly impossible for water authorities to assume practical responsibility for all private supplies, or indeed for changes in water quality occurring within consumers' premises. To take one example alone, one representative water authority's routine sampling programme already involves the performance of 650000 chemical or bacteriological determinations a year on over 200 sources of water, numerous water towers and service reservoirs and a distribution system serving a population of $\mathbf{4 \cdot 4}$ millions ( $H$. Fennel, personal communication). This is an immense workload; to add the burden of several thousand small private supplies would be impossible without a very large increase in resource. The ultimate responsibility for private supplies must rest largely with local authorities, discharged through Medical Officers for Environmental Health (MOEH) and Environmental Health Officers (EHO), and where possible with the close collaboration of the PHLS network of laboratories. Some continued involvement of MOEH, EHOs and PHLS in the regular monitoring of public supplies is surely also desirable, in that they are concerned anyway with the diagnosis, epidemiology and control of any incident, suspect or real, of waterborne disease, including the laboratory isolation, characterization and comparison of pathogens from patients and from suspect water samples. Indeed, this is the 'raison d'être' for the PHLS and it is better that it should be actively concerned with preventative work than only used as a fire brigade when something untoward happens.

There is another area, bristling with problems, which also falls within the scope of the E.C. Directive. That is the notoriously difficult one of monitoring and ensuring the quality of drinking water on board ship, or in aeroplanes or trains; there are also difficulties with other tanked water supplies such as those found in many of our hospitals and schools. It will be interesting to see how effectively these are brought under the control of the relevant authorities.

The principles governing the provision of adequate supplies of safe drinking water have been known for years. It is a mark of the current upsurge of interest in this field that we have not only had the E.C. Directive and a revision of Report 
71 but that there is also imminent a revision of the WHO International Standards for Drinking Water. This will contain specific guidelines for the application of drinking water criteria responsive to the needs and realities prevailing in the developing world, including guidance on what to do when the recommended standards are not met (Witt, 1982). The determination of 'safe' levels of microbiological pollutants in water may present difficulties, especially in tropical countries. Although coliform bacteria are in regular use as indicators of faecal contamination there are problems and limitations with warm tropical waters (Wright, $1982 a, b$ ). It is pleasing to note that the British emphasis on $E$. coli as the essential primary indicator of faecal pollution is becoming more widely appreciated. Indeed, as Report 71 states, it is to be hoped that this revised edition will continue to prove useful not only in the United Kingdom but throughout the world.

\section{REFERENCES}

Campbell, E. P. (1959). Statement on community water supply program. In: Hearings on Mutual Security Act of 1959, Committee on Foreign Relations, U.S. Senate, 86th Congress, 1 st Session, pp. 754-761, May 181959 (cited by World Health Organisation Monograph Series, no. 63, 1976, Surveillance of Drinking Water Quality, p. 13).

DHSS (1982). The Bacteriological Examination of Drinking Water Supplies. 5th ed. Report on Public Health and Medical Subjects, no. 71. London: HMSO.

DOE \& WO (1982). Joint Circular from the Department of the Environment (DOE 20/82) and the Welsh Office (WO 33/82) on the EC Directive relating to the Quality of Water Intended for Human Consumption (80/778/EEC). London: HMSO.

European Community (1980). Council Directive No. 80/778/EEC of $15 \mathrm{July} 1980$ relating to the quality of water intended for human consumption. Official Journal of the European Communities, no. L229, 11.

PHLS \& SCA (1980a). A comparison between minerals - modified glutamate medium and lauryl tryptose lactose broth for the enumeration of Escherichia coli and coliform organisms in water by the multiple tube method, by a Joint Committee of the Public Health Laboratory Service and the Standing Committee of Analysts. Journal of Hygiene 85, 35.

PHLS \& SCA (1980b). Single tube confirmatory tests for Escherichia coli, by a Joint Committee of the Public Health Laboratory Service and the Standing Committee of Analysts. Journal of Hygiene 85, 51.

PHLS \& SCA (1980c). Membrane filtration media for the enumeration of coliform organisms and Escherichia coli in water: comparison of Tergitol 7 and lauryl sulphate with Teepol 610, by a Joint Committee of the Public Health Laboratory Service and the Standing Committee of Analysts. Journal of Hygiene 85, 181.

PHLS \& SCA (1981). A comparison of confirmatory media for coliform organisms and Escherichia coli in water, by a Joint Committee of the Public Health Laboratory Service and the Standing Committee of Analysts. Journal of Hygiene 87, 369.

WHO (1970). European Standards for Drinking Water, 2nd ed. World Health Organisation, Geneva.

WHO (1971). International Standards for Drinking Water, 3rd ed. World Health Organisation, Geneva.

WHO (1976). Surveillance of Drinking Water Quality. Monograph Series No. 63. World Health Organisation, Geneva.

WITT, V. M. (1982). Developing and applying international water quality guidelines. Journal of the American Water Works Association 74, 178-181. 
WRIGHT, R. C. (1982a). A medium for the rapid enumeration of Escherichia coli in the presence of other faecal coliforms in tropical waters. Journal of Hygiene 88, 265-273.

WRIGHT, R. C. (1982b). A comparison of levels of faecal indicator bacteria in water and human faeces in a rural area of a tropical developing country (Sierra Leone). Journal of Hygiene 89, 69-78. 